\title{
HUBUNGAN ANTARA KNOWLEDGE-TECHNOLOGY-INNOVATION (KTI), COMMITMENT, COMPETENCE, LEADERSHIP, GOVERNMENT POLICY, HUMAN CAPITAL, DAN COMPETITIVE ADVANTAGE
}

\author{
Darjat Sudrajat \\ Management Department, School of Business Management, BINUS University \\ Jln. K. H. Syahdan No. 9, Palmerah, Jakarta Barat 11480 \\ sudrajat.darjat@yahoo.com
}

\begin{abstract}
In current tight competitive situation, companies always try to create differentiation anytime to achieve better and sustainable performance. Rapid and unpredictable changes insist the companies should always be innovative, so that aspects of globalization, e-business, technology innovation, creativity, global competition, knowledge creation, diffusion of new technologies and knowledge revolution should be sources of performance and competitiveness improvement. Therefore, to maintain core competencies and competitive advantage, the companies should develop continuous innovation, technology learning, and knowledge management. Knowledge-Technology-Innovation (KTI) can be a driver for country's development and growth. Japan, South Korea, and Singapore are the countries that have limited natural and human resources, but able to achieve sustainable economic development. KTI is not only to be practiced at individual and organizational level, but also can be implemented at the community, national, or state level. KTI, therefore, can encourage expected competitive advantage creation and become a decisive factor for a country to achieve stable and sustainable economic growth. This research intends to analyze relationships of KTI, competitive advantage, commitment, leadership, human capital, government policy, and competence. This research used correlational method and literature study approach. The result of this research is a relationship model of each of these aspects that can be used as a framework for further research. The relationships model is as follows: Leadership, competence, and human capital (as independent variables) have direct relationship (influence) on competitive advantage (dependent variable) or indirectly (through KTI as an intervening variable); KTI has direct relationship (effect) on competitive advantage; Government policy and commitment are moderator variables for relationship of KTI and competitive advantage.
\end{abstract}

Keywords: KTI, competitive advantage, leadership, human capital, government policy

\begin{abstract}
ABSTRAK
Dalam situasi persaingan yang sangat ketat sekarang perusahaan selalu berusaha menciptakan diferensiasi setiap saat untuk mencapai kinerja yang lebih baik secara berkelanjutan. Perubahan yang makin cepat dan sulit diprediksi menuntut perusahaan untuk harus selalu inovatif, sehingga aspek globalisasi, e-bisnis, inovasi teknologi, kreativitas, persaingan global, penciptaan pengetahuan, difusi teknologi baru, dan revolusi pengetahuan harus menjadi sumber peningkatan kinerja dan daya saing perusahaan. Oleh sebab itu, untuk menjaga kompetensi inti dan keunggulan bersaing, maka perusahaan harus mengembangkan inovasi yang berkelanjutan, pembelajaran teknologi dan manajemen pengetahuan. Knowledge-Technology-Innovation (KTI) dapat menjadi motor penggerak pembangunan dan pertumbuhan suatu negara. Jepang, Korea Selatan, dan Singapura adalah negara yang memiliki sumber daya alam dan manusia relative rendah, tetapi sanggup mencapai pembangunan ekonomi secara berkelanjutan. KTI bukan hanya praktik di tingkat individu dan organisasis, melainkan menjadi sangat penting dilihat dan diterapkan pada tingkat komunitas, nasional, atau negara. Dengan demikian, KTI dapat mendorong terciptanya keunggulan bersaing sesuai dengan yang diharapkan dan telah menjadi faktor yang menentukan bagi suatu negara dalam mencapai pertumbuhan ekonomi yang stabil dan berkelanjutan. Penelitian dilakukan untuk mengetahui hubungan aspek KTI, competitive advantage, commitment, leadership, human capital, government policy, dan competence. Penelitian dilakukan berdasarkan metode korelasional dengan pendekatan studi literature, kemudian disimpulkan dalam suatu model hubungan antara aspek-aspek tersebut yang dapat dijadikan sebagai kerangka penelitian lebih lanjut. Berdasarkan hasil analisis yang telah dilakukan, dapat disimpulkan hubungan antara aspek-aspek tersebut adalah sebagai berikut: Leadership, competence, dan human capital (sebagai variabel independen) mempunyai hubungan (pengaruh) langsung terhadap competitive advantage (variabel dependen) atau tidak langsung (melalui KTI sebagai variabel perantara); KTI mempunyai pengaruh langsung dengan competitive advantage; Government policy dan commitment merupakan variabel moderator (pendorong) bagi hubungan KTI dengan competitive advantage.
\end{abstract}

Kata kunci: KTI, competitive advantage, leadership, human capital, government policy 


\section{PENDAHULUAN}

Knowledge, technology, dan innovation (KTI) merupakan aspek-aspek utama bagi suatu organisasi atau negara untuk dapat memenangkan persaingan dalam era globalisasi sekarang ini (Lundvall, 2003; Nelson \& Romer, 1996; Edquist, 2001). Namun kontribusi KTI dalam pembangunan ekonomi Indonesia sampai dengan sekarang ini agaknya masih jauh dari harapan. Kondisi ini jauh berbeda dengan beberapa negara di Asia, terutama negara yang kurang memiliki sumber daya alam besar seperti Jepang, Korea Selatan, dan Singapura. Negara-negara ini walaupun relatif rendah dalam pemilikan sumber daya alam dan manusia, sanggup mencapai pembangunan ekonomi secara berkelanjutan. Sehingga, peranan KTI tentu tidak bisa disangsikan telah menjadi faktor yang menentukan bagi negara-negara tersebut berhasil dalam mencapai pertumbuhan ekonomi yang stabil dan berkelanjutan.

Berdasarkan Total Factor Productivity (TFP), yaitu salah satu ukuran yang dapat digunakan untuk mengetahui peran KTI sebagai sumber pertumbuhan ekonomi, tercatat bahwa TFP Indonesia hanya sebesar 1,38\% (Bank Indonesia, 2007). Hal ini berarti bahwa sumber pertumbuhan ekonomi nasional masih didominasi oleh faktor kapital. Kondisi ini berhubungan dengan rendahnya daya saing KTI itu sendiri. Adapun rendahnya daya saing tersebut dapat diperhatikan melalui indeksideks sebagai berikut. Pertama, Indeks Pembangunan Manusia (IPM) atau Human Development Index (HDI). United Nations for Development Programs (UNDP) pada 2006 menetapkan bahwa IPM Indonesia (sebagai indeks gabungan dari tingkat harapan hidup, tingkat partisipasi pendidikan dan tingkat pendapatan per kapita riil) pada peringkat ke-112 dari 177 negara yang dianalisis. Peringkat ini posisinya jauh dari Filipina (82), Thailand (74), dan Malaysia (55). Bahkan posisi ini makin jauh di bawah jika dibandingkan dengan Brunei Darussalam (peringkat 31) dan Singapura (23). Peringkat daya saing Indonesia tercatat hanya satu tingkat di atas Vietnam yang berada pada peringkat ke 113. Indeks IPM Indonesia hanya lebih baik dari Kamboja, Myanmar, dan Laos yang menempati peringkat masing-masing 128, 130, dan 133. Kedua, Growth Competitive Index (GCI) yaitu ukuran daya kompetisi negara yang menggunakan parameter lingkungan ekonomi makro, perkembangan lembaga publik, dan inovasi teknologi. World Economic Forum (WEF) dalam Global Competitiveness Report 2006 memosisikan Indonesia pada peringkat ke-54 dari 55 negara. Seandainya dibandingkan dengan negara-negara ASEAN 6, peringkat tersebut berada pada posisi terendah. Singapura menempati peringkat ke-5, Malaysia peringkat ke-21, Thailand peringkat ke-26, Filipina peringkat ke-52, dan Vietnam pada peringkat ke-53. Ketiga, indeks daya saing bisnis (Business Competitive Index, IBC). Dari sumber yang sama dengan di atas, IBC Indonesia pada 2006 dinyatakan berada pada peringkat ke-58. Jika dibandingkan negara ASEAN 6, Indonesia hanya sedikit lebih baik dari Filipina yang berada pada peringkat ke 60, tetapi lebih buruk dibandingkan dengan negara Vietnam yang berada pada peringkat ke-55. Apalagi jika dibandingkan dengan Singapura yang berada pada peringkat ke 3, Malaysia pada peringkat ke-16, dan Thailand pada peringkat ke-21. Indeks ini mengukur daya saing bisnis berdasarkan parameter sofistikasi strategi dan operasi perusahaan dan kualitas lingkungan bisnis nasional.

Berdasarkan publikasi RISTEK (2004) disebutkan bahwa penyebab rendahnya Growth Competitiveness Index (GCI) tersebut adalah karena makin lemahnya kemampuan teknologi. Peringkat kemampuan teknologi nasional (diukur dari tingkat inovasi, telematika, dan alih teknologi) menurun dari peringkat ke-65 tahun 2002 menjadi peringkat ke-71 pada 2006. Sedangkan dalam Business Competitive Index (BCI), rendahnya BCI tahun 2006 disebabkan memburuknya strategi dan operasi perusahaan nasional. Dalam hal ini peringkat Indonesia menurun dari peringkat ke-52 pada 2004 menjadi peringkat ke-54 pada 2006. 
Bukti empiris lain untuk mengetahui rendahnya daya saing KTI ini dapat pula dilihat dari ranking daya saing Indonesia di dunia diukur dari kinerja ekonomi, efisiensi pemerintah, efisiensi bisnis dan infrastruktur. Dalam laporan tahunan Daya Saing Dunia (World Competitiveness Yearbook) tahun 2004 yang disusun oleh Institute for International Management Development (IIMD), peringkat Indonesia terus menurun sejak tahun 2000 dengan menggunakan perhitungan keempat faktor di atas. Dari 60 negara di dunia yang dipakai perbandingan, Indonesia pada 2006 menempati peringkat ke-54, menurun dibandingkan peringkat yang diperolehnya pada 2000 yakni pada peringkat ke-43. Dibandingkan dengan negara ASEAN 5, seperti Malaysia, peringkat negara ini berada pada ranking ke-16. Sedangkan Singapura, Thailand, dan Filipina berada pada ranking 2, 23, dan 51. Simpulannya, dengan menggunakan indikator tersebut, perkembangan daya saing KTI nasional selama ini belum memuaskan.

Oleh sebab itu, tantangan-tantangan sekarang ini yang mencakup globalisasi, ekonomi pengetahuan (knowledge-based economy), dan evolusi teknologi telah mendorong beberapa negara dan organisasi mencari cara-cara baru untuk mempertahankan keunggulan bersaingnya. Adapun pemahaman yang ada sekarang adalah bahwa keberhasilan tersebut tergantung pada tingkat kompetensi yang lebih tinggi dari individu-individu sumber daya manusia. Pada akhirnya, individuindividu tersebut akan menjadi aset yang berharga dan dapat diakui sebagai human capital. Sehubungan dengan hal tersebut, maka organisasi-organisasi global dewasa ini lebih memfokuskan waktu dan perhatian mereka pada memaksimalkan nilai dari sumber daya manusianya. Dengan makin terintegrasinya organisasi-organisasi di dunia (perusahaan, organisasi nonpemerintah, organisasi pemerintah) dan makin kurang relevannya batas-batas geografi, kebutuhan untuk mengidentifikasi, mengembangkan, dan menghubungkan talenta-talenta dunia menjadi sangat penting (IBM Global Human Capital 2008).

Knowledge, technology, dan innovation (KTI) dapat menjadi motor penggerak pembangunan dan pertumbuhan Indonesia. Sehingga KTI bukan hanya praktik di tingkat individu dan organisasi bisnis, melainkan menjadi sangat penting dilihat dan diterapkan pada tingkat komunitas, nasional, atau negara. Dengan demikian, KTI dapat mendorong terciptanya keunggulan bersaing (competitive advantage) sesuai dengan yang diharapkan. Sehubungan dengan itu, maka tujuan penelitian ini adalah untuk dapat menganalisis secara konseptual hubungan variabel-variabel KTI, keunggulan bersaing (competitive advantage), commitment, leadership, government policy, human capital, dan competence, sehingga jelas variabel mana saja sebagai variabel independen, dependen, mediator, atau moderator. Penelitian ini diharapkan dapat memberikan kontribusi khsusnya terhadap pengembangan konsep KTI dengan faktor-faktor yang memengaruhinya melalui pengembangan suatu kerangka atau model penelitian yang dapat digunakan untuk proses penelitian lebih lanjut.

Dengan berbagai cara, perusahaan-perusahaan berusaha berbeda dari hari kemarin dan berusaha jauh lebih baik lagi untuk hari esok. Perusahaan-perusahaan menghadapi perubahan yang konstan dan tantangan yang kuat baik di dalam maupun di luar lingkungan mereka. Sementara itu, globalisasi, e-bisnis, inovasi teknologi, kreativitas, persaingan global, penciptaan pengetahuan, difusi teknologi baru dan revolusi pengetahuan memiliki dampak yang cukup besar pada keberhasilan bersaing perusahaan. Untuk menjaga kompetensi inti dan keunggulan bersaing, maka perusahaanperusahaan membutuhkan suatu inovasi yang berkelanjutan, pembelajaran teknologi dan manajemen pengetahuan (Hitt et al., 2012). Proses penciptaaan pengetahuan dalam era inovasi adalah hal yang mendasar, adapun penciptaaan pengetahuan terjadi dalam benak individu-individu (manusia) yang berada dalam organisasi. Tanpa individu-individu tersebut, organisasi tak mampu menciptakan pengetahuan yang dibutuhkannya untuk melakukan berbagai inovasi (dalam berbagai penelitian konseptual maupun empiris). Pengetahuan adalah kesadaran, informasi, atau pemahaman tentang fakta-fakta, aturan, prinsip, pedoman, konsep, teori, atau proses yang diperlukan untuk keberhasilan melakukan tugas (Marelli et al., 2005). Pengetahuan mungkin konkret, spesifik, dan mudah diukur, atau lebih kompleks, abstrak, dan sulit untuk dinilai. Pengetahuan diperoleh melalui pembelajaran dan pengalaman (Marelli et al., 2005). 
Menurut Jashapara (2013), secara praktis pengetahuan (knowledge) adalah informasi yang dapat ditindaklanjuti. Sehingga memungkinkan sesorang dapat membuat keputusan yang lebih baik dan memberikan input yang efektif untuk dialog dan kreativitas dalam organisasi. Sedangkan menurut Probst (1998), pengetahuan adalah keseluruhan kognisi dan keterampilan yang digunakan oleh manusia untuk memecahkan masalah. Nonaka dan Krogh (2009), menyatakan bahwa pengetahuan (knowledge) merupakan kepercayaan yang dapat dipertanggungjawabkan dan sesuatu yang eksplisit sekaligus terpikirkan (tacit). Dalam organisasi, pengetahuan diperoleh dari individu atau kelompok yang memiliki pengetahuan atau kadang kala dari rutinitas organisasi. Pengetahuan dapat diperoleh melalui media yang terstruktur, seperti buku, dokumen, hubungan orang ke orang yang berkisar dari pembicaraan ringan sampai ilmiah. Pengetahuan merupakan suatu yang eksplisit sekaligus tacit, beberapa pengetahuan dapat dituliskan, dikerjakan, dan diformulasikan dalam bentuk kalimat atau diekspresikan dalam bentuk gambar. Meskipun begitu, ada pula pengetahuan yang terkait erat dengan pengalaman fisik, petunjuk praktis, dan intuisi yang melaluinya pengetahuan terbatinkan, seperti sulit sekali digambarkan kepada orang lain.

Pengetahuan dapat membuat daya saing perusahaan. Menurut Barney (1991), terdapat empat kriteria yang dapat dipakai untuk membantu perusahaan mengidentifikasikan sumber daya yang dapat mendukung keunggulan daya saing, yaitu berharga (valuability), langka (rarity), sulit ditiru (inimibality), dan sulit digantikan (substitutability). Peningkatan daya saing organisasi sangat tergantung kepada sumber daya yang berbasis pengetahuan, seperti teknologi know-how dan pemahaman yang mendalam kepada para pelanggannya. Pengetahuan telah menjadi sumber daya paling berguna di dalam dunia bisnis saat ini. Pengetahuan meliputi teori dan konsep serta pengetahuan tacit yang diperoleh sebagai hasil dari pengalaman melakukan tugas-tugas tertentu (Winterton et al., 2006). Inovasi juga diakui sebagai alat yang dapat mendorong peningkatan daya saing (Powell \& Snellman, 2004). Inovasi adalah implementasi ide-ide kreatif yang berhasil dalam suatu organisasi (Schaper et al., 2013). Sedangkan menurut Barringer dan Ireland (2013), bahwa inovasi merupakan proses penciptaan sesuatu yang baru. Secara generik, inovasi didefinisikan sebagai 'adopsi' dan 'difusi' terhadap ide atau gagasan baru dalam perusahaan (Thomke et al., 1998; Damanfour \& Schneider, 2008). Penciptaan gagasan baru atau adopsi sesuatu yang baru dapat dikatakan sebagai inovasi jika dapat dikomersialisasikan menjadi sebuah produk atau jasa yang diinginkan konsumen. Inovasi yang baik akan menghasilkan produk atau jasa baru yang berkualitas, dengan biaya yang lebih rendah, improvisasi produk dengan atribut baru, dan menghasilkan produk yang berbeda dengan sebelumnya (Berry et al., 2010)

Inovasi adalah keberhasilan sosial dan ekonomi berkat diperkenalkannya atau ditemukannya cara-cara baru atau kombinasi baru dari cara-cara lama dalam mentransformasi input menjadi output sedemikian rupa sehingga berhasil menciptakan perubahan besar atau perubahan drastis dalam hubungan antara nilai guna atau nilai manfaat (yang dipersepsikan oleh konsumen dan/atau pengguna) dan nilai moneter atau harga (Fontana, 2011). Definisi ini menjelaskan bahwa inovasi tidak saja berarti "kebaruan" atau sesuatu yang baru, barang dan/atau jasa baru atau sistem produksi baru atau cara memasarkan yang baru; "kebaruan" itu perlu disertai dengan dampak positif bagi konsumen dan produsen; "kebaruan" itu harus menciptakan nilai guna bagi konsumen dan nilai tambah bagi produsen; "kebaruan" yang menghasilkan kesuksesan ekonomi dan sosial, pada konteks inovasi dan penciptaan nilai tingkat individu, organisasi, dan masyarakat (society). Pendorong untuk inovasi di suatu wilayah tergantung pada interaktif, pembelajaran sosial antara semua pelaku ekonomi di wilayah tersebut (Greenwood \& Pike, 2011).

Dalam dunia bisnis saat ini, inovasi sebagai suatu disiplin, belum mencapai tahap perkembangan yang diharapkan dalam memenuhi kebutuhan tertentu yang sangat mendesak (de Bes, 2011). Inovasi adalah kemampuan individu atau organisasi dalam hal membuat alat, produk, atau proses baru, melahirkan sesuatu yang 'baru' yang memungkinkan manusia untuk mencapai sesuatu yang mereka tidak mampu capai sebelumnya (Tidd \& Bessant, 2009). Inovasi tidak hanya mengenai munculnya produk baru atau yang lebih baik, tetapi juga mengenai pemecahan masalah apa yang harus 
muncul pertama kali (Silverstein, et al, 2009). Menurut Estrin (2009), terdapat lima nilai inti dari inovasi yaitu questioning, risk taking, openness, patience, dan trust. Adapun dimensi-dimensi inovasi adalah mencakup inovasi produk, inovasi proses, inovasi posisi, dan inovasi paradigma (Tidd \& Bessant, 2009).

Kemampuan inovasi didefinisikan sebagai kemampuan untuk terus mentransformasikan pengetahuan dan ide-ide menjadi produk baru, proses dan sistem untuk kepentingan perusahaan dan para pemangku kepentingan. Kemampuan inovasi tidak hanya kemampuan untuk menjadi sukses dalam menjalankan sebuah newstream bisnis, atau untuk mengelola kemampuan mainstream. Kemampuan inovasi adalah tentang sintesis kedua paradigma operasi. Inovator yang berprestasi harus memahami hubungan ini. Tantangan untuk semua entrepreneur adalah membangun organisasi yang efektif dan inovatif. Organisasi yang efektif mampu menstransformasi kegiatan entrepreneurial korporat ke dalam strategi perusahaan, yang merupakan hal mendasar dalam mengembangkan pendekatan-pendekatan yang kreatif dan inovatif yang didesain untuk mengembangkan ide-ide dan cara-cara baru dalam melakukan sesuatu (Hisrich \& Kearney, 2013). Menurut Nonaka dan Toyama (2003), penciptaan pengetahuan merupakan esensi dari inovasi.

Dalam suatu industri, perusahaan yang menghasilkan inovasi cenderung melakukan lebih banyak penelitian dan kegiatan hilir dibandingkan meniru inovasi. Akuisisi teknologi sama pentingnya bagi keduanya. Untuk menerapkan strategi inovasi, perusahaan-perusahaan memerlukan kedua kemampuan tersebut untuk memindai lingkungan eksternal, teknologi, dan kemampuan untuk mengintegrasikan teknologi baru. Perusahaan yang menghasilkan inovasi mengharuskan keduanya, sementara perusahaan yang meniru inovasi membutuhkan kemampuan scan saja (Arbussa \& Coenders, 2005).

Di luar hubungannya dengan kehidupan sehari-hari, teknologi adalah kepentingan yang mendesak untuk keunggulan bersaing perusahaan dan negara-negara (Ricken \& Malcotsis, 2011). Perusahaan menciptakan keunggulan kompetitif dengan menciptakan produk baru atau menemukan teknologi baru untuk memproduksi dan memasarkannya. Akses ke faktor-faktor produksi yang melimpah, seperti tenaga kerja atau sumber daya murah, menjadi kurang penting dibandingkan dengan teknologi dan keterampilan untuk menghasilkan produk atau jasa secara efektif atau efisien (Porter, 1990). Untuk negara-negara, dengan asumsi bahwa tujuan utama ekonomi adalah untuk menghasilkan standar hidup yang tinggi, konsep ini hanya berarti jika daya saing merupakan produktivitas nasional (Porter, 1990). Teknologi fisik atau manajerial baru memberikan keunggulan kompetitif dengan meningkatkan produktivitas, pengaturan dasar untuk standar hidup yang lebih tinggi.

\section{Competitive Advantage}

Keunggulan bersaing (competitive advantage) adalah segala sesuatu yang dilakukan perusahaan lebih baik dibandingkan dengan para pesaingnya (David, 2013). Ketika suatu perusahaan dapat melakukan apa yang tidak dapat dilakukan pesaingnya, atau memiliki sesuatu yang pesaing inginkan, maka hal tersebut mencerminkan suatu keunggulan bersaing. Sedangkan menurut Grant dan Jordan (2012), keunggulan bersaing adalah kemampuan suatu perusahaan untuk menghasilkan (atau mempunyai potensi untuk menghasilkan) tingkat keuntungan yang lebih tinggi dibanding pesaingnya yang beroperasi di pasar yang sama secara berkelanjutan.

Suatu keunggulan bersaing yang berkelanjutan (sustained competitive advantage) terjadi jika suatu perusahaan mengembangkan strategi yang para pesaing tidak mengimplementasikannya secara bersamaan, melakukan sesuatu yang lebih baik daripada pesaing lain, atau melakukan sesuatu yang tidak dapat dilakukan oleh pesaing lain (Hitt, et al., 2012). Keunggulan kompetitif yang berkelanjutan (sustained competitive advantage) berarti menunjukkan upaya perusahaan/organisasi dalam jangka panjang yang mampu mempertahankan posisi keunggulan kompetitifnya dalam industri. 


\section{Competence}

Kompetensi adalah suatu kemampuan manusia yang terukur dan diperlukan untuk mencapai kinerja yang efektif. Kompetensi dapat terdiri dari pengetahuan, keterampilan atau kemampuan, karakteristik pribadi, atau sekelompok dua atau lebih dari atribut tersebut. Kompetensi adalah seperti blok bangunan kinerja suatu pekerjaan. Kinerja dari kebanyakan pekerjaan membutuhkan demonstrasi dari berbagai kompetensi secara simultan dan berkelanjutan (Marelli, et al, 2005)

Jadi, kompetensi dapat dianggap sebagai interpretasi kebutuhan bisnis yang berbasis bakat (talenta). Pandangan ini mendefinisikan kompetensi sebagai karakteristik orang yang dapat ditunjukkan, termasuk pengetahuan, keterampilan dan perilaku, yang memungkinkan dilakukan (Winterton, 2006). Definisi tersebut menegaskan bahwa kompetensi menambah nilai dengan cara mengkomunikasikan apa yang orang harus tahu untuk membantu keberhasilan bisnis. Hal ini penting selama masa persaingan. Organisasi yang tertantang umumnya perlu mendapatkan perhatian untuk solusi baru karena pendekatan yang ada sekarang tidak lagi menambah nilai.

Jika kompetensi dan model kompetensi mendukung orientasi baru, maka sumber kompetensi mungkin mencakup hal-hal berikut ini (Zingheim et al, 1996). Pertama, strategi, struktur, dan kultur. Organisasi perlu merespons perubahan yang berkelanjutan pada lingkungan bisnis dan tantangantantangan untuk mencari keunggulan bersaing. Untuk menerapkan arah strategis baru, maka orangorang harus tahu bagaimana bantuan tersebut harus diberikan. Kedua, praktik terbaik dari pemimpin pasar. Praktik sumber daya manusia dapat ditiru dari organisasi yang telah menikmati kesuksesan dalam menyelaraskan orang, proses, dan sistem untuk mendukung perubahan bisnis. Organisasi yang sukses cenderung memiliki pengalaman dalam menafsirkan dan mengkomunikasikan arah baru sumber daya manusianya.

Kompetensi terdiri dari komponen yang emergent, dinamis, dan terposisikan, dan tidak hanya didasarkan pada pengalaman dan prestasi masa lalu (Lindgren et al. 2001). Ada empat karakteristik kompetensi yang harus dimiliki dalam rangka menghasilkan competitive advantage, yakni harus berharga, langka, sulit ditiru, dan dapat dieksploitasi secara organisasi (VRIO) (Nieminen, 2007). Dalam rangka mendapatkan competitive advantage perusahaan perlu mengembangkan pengetahuan dan kompetensi inti yang langka, berharga dan dapat digunakan secara organisasi, tetapi sulit bagi orang luar untuk meniru ( Barney, 1991).

\section{Government Policy}

Pemerintah di seluruh dunia memperluas dan memperdalam dukungan mereka untuk inovasi di sektor swasta dan ekonomi secara umum. Dalam hal inovasi dan teknologi, pemerintah mungkin memiliki beberapa tujuan, diantaranya untuk mendorong pembentukan atau pertumbuhan kewirausahaan dengan penciptaan teknologi baru yang mampu bersaing di tingkat global. Pemerintah juga mungkin ingin mendorong perusahaan-perusahaan lokal yang sudah ada untuk mengambil langkah-langkah modernisasi proses bisnis dan infrastruktur teknologi mereka.

Inisiatif-inisiatif pemerintah yang mendorong pendatang-pendatang baru untuk fokus pada produk atau jasa yang inovatif memiliki nilai tambah, yaitu menimbulkan efek penguatan untuk menekan pelaku pasar yang ada sekarang untuk bersaing melalui modernisasi dan inovasi. Para pemain yang sedang berkuasa akan merespons hanya ketika mereka merasakan konsekuensi dari keputusan tersebut. Jika mereka terus kehilangan uang namun tahu pemerintah akan menyelamatkan mereka dengan cara apa pun dalam rangka menjaga lapangan pekerjaan, mereka akan memiliki sedikit motivasi untuk bersaing atau berinovasi. Setiap negara memiliki aset, defisit, dan industri yang khas pada berbagai tahap kematangan ekonomi. Semua bentuk lingkungan ini merupakan wilayah, tempat kebijakan dan insentif pemerintah akan diberlakukan. Negara-negara yang memahami profil ekonomi khusus mereka, dan merancang strategi yang tepat sesuai dengan profil tersebut, memiliki peluang untuk meningkatkan kesuksesan dalam mengembangkan inovasi. 
Industrialisasi selalu merupakan tujuan utama dari strategi pembangunan dan kebijakan pemerintah. Melalui industrialisasi, negara-negara berkembang bercita-cita untuk mencapai pertumbuhan yang lebih tinggi, dan akhirnya mencapai status negara maju. Namun tetap diragukan apakah pendekatan industri dalam pembuatan kebijakan di negara berkembang memang telah berhasil dalam mengubah perekonomian mereka. Dalam mendukung pembangunan industri sektor swasta, maka fokus utamanya adalah pada kebijakan industri yang didorong oleh inovasi untuk mendorong peningkatan keterampilan, meningkatkan pertumbuhan industri dan menghasilkan ekspor kelas dunia. Hal ini menjelaskan mengapa pembuatan kebijakan harus mengejar inovasi sebagai penggerak utama dalam pembangunan ekonomi untuk dimasukkan ke dalam perspektif pentingnya kebijakan industri yang berbasiskan inovasi.

\section{Human Capital}

Laporan Organisation for Economic Co-operation and Development, OECD, (1998) mendefinisikan bahwa human capital sebagai pengetahuan, keterampilan, kompetensi dan atribut yang terkandung dalam individu yang relevan dengan kegiatan ekonomi (Folloni \& Vittadini, 2010). Human capital secara ekspansif mencakup pengertian manusia sebagai pencipta yang membingkai pengetahuan, keterampilan, kompetensi, dan pengalaman yang diawali oleh hubungan yang terusmenerus antara diri dan lingkungan. Akibatnya, sumber daya manusia secara bersamaan meliputi baik kerangka konsep untuk menghasilkan nilai-nilai tertentu maupun 'endogen' untuk menghasilkan makna diri tersebut. Dalam rangka menciptakan nilai-nilai secara independen atau dependen, tidak ada keraguan bahwa pembelajaran melalui pendidikan dan pelatihan dapat menjadi suatu hal yg penting dalam mendefinisikan konsep human capital. Mengingat pengalaman dapat disimpulkan sebagai suatu kategori pengetahuan, maka human capital adalah sinonim dengan pengetahuan yang tertanam dalam individu (Dae-Bong, 2009).

David dan Foray (2002), menyimpulkan bahwa kualitas human capital dan penciptaan ide-ide baru (inovasi) dan pengetahuan merupakan penggerak kemajuan yang menciptakan perbedaan dalam produktivitas dan pertumbuhan di negara-negara yang berbeda. Banyak peneliti yang menegaskan bahwa terdapat hubungan yang erat antara inovasi dan human capital. Menurut Nelson dan Phelp (1966), untuk mengintegrasikan gagasan tersebut maka adopsi teknologi baru tergantung pada kapasitas human capital. Daya serap negara ditentukan oleh tingkat pendidikan penduduknya. Menurut Benhabib dan Spiegel (2002) terdapat efek positif yang signifikan secara statistik dari human capital sehubungan dengan kesenjangan teknologi. Penelitian lain oleh Xu (2000) menegaskan pentingnya tingkat tertentu human capital di negara yang memperoleh manfaat dari arus teknologi.

\section{Leadership}

Leadership adalah kemampuan untuk memengaruhi suatu kelompok terhadap pencapaian suatu visi atau tujuan-tujuan tertentu (Robbins \& Judge, 2011). Sedangkan Yukl (2012) mendefinisikan kepemimpinan sebagai proses memengaruhi orang lain untuk memahami dan menyetujui tentang hal yang perlu dilakukan dan cara melakukannya, dan proses memfasilitasi upaya individu dan kolektif untuk mencapai tujuan bersama. Sedangkan Northouse (2012) mendefinisikan kepemimpinan sebagai suatu proses dimana seorang individu memengaruhi sekelompok individu lainnya untuk mencapai tujuan bersama. Definisi tersebut menunjukkan berbagai elemen-elemen utama bagi fenomena kepemimpinan. Beberapa di antaranya yaitu: (a) kepemimpinan adalah proses; (b) kepemimpinan melibatkan memengaruhi orang lain; (c) kepemimpinan terjadi dalam konteks kelompok; (d) kepemimpinan melibatkan pencapaian tujuan; dan (e) tujuan ini dicapai oleh pemimpin dan pengikutnya secara bersama-sama.

Seorang pemimpin adalah orang yang memilih, melengkapi, melatih, dan memengaruhi satu atau lebih pengikut dengan beragam hadiah, kemampuan, dan keterampilan dan memfokuskan pengikutnya terhadap misi dan sasaran organisasi sehingga pengikutnya merasa rela dan antusias 
mengeluarkan energi spiritual, emosional, dan fisik dalam upaya yang terkoordinasi untuk mencapai misi dan tujuan organisasi tersebut (Winston \& Patterson, 2006)

\section{Commitment}

Salah satu faktor yang berpengaruh dalam pengembangan teknologi adalah faktor politik, yaitu komitmen pemerintah yang dituangkan dalam bentuk kebijakan dan program yang meliputi pengembangan regulasi, pengembangan kelembagaan dan pengembangan program insentif. Misalnya, kebijakan pemerintah dalam pembangunan ilmu pengetahuan dan teknologi (IPTEK) nasional (penelitian, pengembangan dan penerapan iptek) dituangkan dalam Kebijakan strategis nasional ilmu pengetahuan dan teknologi (Jakstranas Iptek) yang ditetapkan 5 tahun sekali (Muchtadi, 2006).

Salah satu faktor yang cukup signifikan dalam perkembangan inovasi IPTEK Korea Selatan adalah komitmen kuat pemerintah terhadap pengembangan iptek berbasis teknologi nasional ditunjukkan dengan membidani lahirnya puluhan pusat riset yang menjadi tenaga penggerak alias driving force bagi dinamika evolusi perkembangan iptek Korsel.

\section{METODE}

Penelitian menggunakan metode korelasional dengan pendekatan studi literatur yang berhubungan dengan aspek-aspek KTI (knowledge-technology-innovation), commitment, competence, leadership, government policy, human capital, dan competitive advantage. Berdasarkan metode dan pendekatan tersebut kemudian disimpukan suatu pola hubungan di antara faktor-faktor atau variabelvariabel yang bersangkutan.

\section{HASIL DAN PEMBAHASAN}

\section{Knowledge, Technology, Innovation (KTI) - Competitive Advantage}

Beberapa hasil penelitian menunjukkan bahwa knowledge, technology, dan innovation (KTI) secara individu atau simultan memengaruhi secara langsung competitive advantage (Barney, 1991; Murmann, 2003; Alwis \& Hartmann, 2008; Costa and Cabral, 2009; Hussain \& Ilyas, 2011; Waheed et al., 2012; Hana, 2013; Lahovnik \& Breznik, 2013). Keunggulan bersaing akan diperoleh ketika perusahaan-perusahaan menilai tacit knowledge mereka karena explicit knowledge adalah pengetahuan yang sudah kita ketahui dan umum sesuai sifatnya. Tacit knowledge dapat menjadi sumber potensi dan peluang yang sangat besar berupa penemuan dan kreativitas (Alwis \& Hartman, 2008).

Para manajer dan akademisi telah mengakui bahwa pengetahuan sebagai sumber utama keunggulan bersaing (Grant, 1997). Inovasi, merupakan bentuk utama dari penciptaan pengetahuan organisasi, tidak dapat dijelaskan secara memadai dalam hal pengolahan informasi atau pemecahan masalah. Inovasi lebih dipahami sebagai suatu proses organisasi menciptakan dan mendefinisikan masalah dan kemudian secara aktif mengembangkan pengetahuan baru untuk menyelesaikannya (Nonaka, 2003)

Hasil empiris lain yang disajikan oleh Chen et al dalam Costa dan Cabral (2009), menunjukkan bahwa hubungan pembelajaran dan kapasitas absortif mempunyai pengaruh positif pada kinerja inovasi, dan kinerja inovasi mempunyai pengaruh positif terhadap keunggulan bersaing. Oleh karena itu, kinerja inovasi memediasi hubungan pembelajaran dan pengetahuan terhadap keunggulan 
bersaing. Menurut Karlsson et al. (2012) knowledge diakui sebagai salah satu faktor yang sangat penting pada tingkat mikro, regional, nasional dan supraregional untuk mempertahankan dan mengembangkan daya saing.

Menurut Barney (1991), inovasi adalah salah satu cara paling penting untuk mencapai keunggulan bersaing. Inovasi memengaruhi keunggulan bersaing perusahaan dengan cara-cara yang berbeda-beda dan hubungan tersebut juga dimoderatori oleh lingkungan persaingan (Costa \& Cabral, 2009). Oleh karena itu, untuk menciptakan competitive advantage dibutuhkan sumber daya yang unique dan valuable (Collis \& Montgomery, 2008). Sedangkan menurut Zack (2003), sumber daya yang bisa dikatakan paling unique dan inimitable adalah sumber daya pengetahuan (knowledge). Knowledge digunakan untuk mengelola dan mengkoordinasikan sumber daya yang dimiliki perusahaan untuk berkompetisi. Perusahaan yang memiliki sumber daya knowledge melebihi pesaingnya akan lebih inovatif dan memberikan "nilai" yang lebih besar kepada konsumen. Jika knowledge dijadikan sumber stratejik yang paling penting, maka kemampuan untuk mengumpulkan, mengintegrasikan, menyimpan, menyebarkan, serta penerapannya merupakan kapabilitas yang paling penting untuk membangun dan mempertahankan competitive advantage.

Kreativitas dan inovasi mempunyai peranan yang sangat penting dalam menjalankan bisnis perusahaan. Perusahaan tidak akan menikmati sustainable competitive advantage hanya dengan memproses resources capabilities. Mereka harus dapat mengkombinasikan resources dengan cara baru yang berbeda atau mengembangkan capabilities baru untuk mendapatkan sustainable competitive advantage. Hal ini mungkin dilakukan melalui pemikiran kreatif dan inovatif dan pendekatan terhadap competitive advantage. Perusahaan tidak dapat mencapai sustainable competitive advantage hanya dengan mengikuti product market based strategy atau resource based strategy saja. Sumber daya pengetahuan memberikan basis yang kuat bagi perusahaan untuk menciptakan sustainable competitive advantage. Untuk mengembangkan knowledge-based strategy dalam rangka penciptaan competitive advantage yang sustainable perlu upaya yang berkesinambungan, membutuhkan pemahaman ke depan serta perencanaan yang komprehensif. Karena organisasi terus berusaha untuk memenuhi berbagai tantangan, maka pengetahuan semakin dilihat sebagai hal yang sangat penting bagi inovasi dan untuk memproduksi produk yang intensif pengetahuan dan jasa yang diinginkan oleh pasar. Sehingga untuk mempertahankan keunggulan kompetitif yang berkelanjutan, organisasi atau negara harus mengelola pengetahuannya dengan baik (Nonaka, 2003)

\section{Competence, Leadership, and Human Capital - KTI (Knowledge, Technology, Innovation)}

Beberapa hasil penelitian juga menyatakan bahwa competence, leadership, dan human capital secara individu dan simultan berpengaruh langsung terhadap KTI (Lindgren, 2001; Benhabib \& Spiegel, 2002; Kandampully, 2002; Crawford, 2004; Agbor, 2008; Denti, 2011; de Jong et al., 2003; Wang et al., 2008; Hussain \& Ilyas, 2010; Luckanicova \& Malikova, 2011; ).

Pemimpin harus memengaruhi tim dan karyawannya untuk berinovasi dengan berbagai cara. Namun banyak faktor pada tingkat individu, tim, dan organisasi dapat memfasilitasi atau merusak upaya pemimpin dalam memengaruhi hasil inovasi (Denti, 2011). Kepemimpinan secara luas diakui sebagai faktor penentu keberhasilan untuk pengembangan jasa atau produk baru. Sehingga inventarisasi perilaku pemimpin dan faktor-faktor lainnya mungkin dapat meningkatkan perilaku inovatif dari rekan kerja (de Jong, 2003).

Kepemimpinan dapat menjadi penentu penting dari perilaku inovatif individu, terutama di perusahaan-perusahaan kecil. Definisi saat ini mengenai kepemimpinan mencerminkan asumsi bahwa hal itu melibatkan suatu proses pengaruh disengaja diberikan oleh seseorang atas orang lain untuk membimbing, membangun dan memfasilitasi kegiatan dan hubungan di kelompok atau organisasi. Dalam konteks ini, kepemimpinan berkaitan dengan perilaku para pemimpin yang memengaruhi rekan kerja untuk berperilaku inovatif. 


\section{Competence, Leadership, dan Human Capital - Competitive Advantage}

Beberapa hasil penelitian menyatakan bahwa competence, leadership, dan human capital secara individu maupun simultan berpengaruh langsung terhadap competitive advantage (Khan \& Anjum, 2013; Al-Zoubi, 2012; Agha et al., 2012; Wright, et al., 1993). Menurut Khan dan Anjum (2013), bahwa terdapat hubungan yang kuat antara leadership dengan competitive advantage. Leadership adalah sumber kunci keunggulan bersaing. Sedangkan menurut Agha et al. (2013), agar tetap kompetitif dan memperoleh keunggulan bersaing, para manajer dapat mencoba untuk meningkatkan kinerja organisasi dengan mengelola setiap dimensi dari kompetensi (inti). Sumber daya manusia atau human capital selalu merupakan sumber yang potensial untuk keunggulan bersaing yang berkelanjutan (Wright et al., 1993)

\section{SIMPULAN}

Berdasarkan studi literatur dan pembahasan, maka hubungan aspek-aspek knowledge, technology, dan innovation (KTI), competitive advantage, commitment, leadership, human capital, government policy, dan competence adalah sebagai berikut. Pertama, leadership, competence dan human capital (sebagai variabel independen) dapat mempunyai hubungan langsung dengan competitive advantage (variabel dependen) atau tidak langsung (melalui KTI sebagai variable perantara/intervening). Kedua, KTI mempunyai hubungan langsung dengan competitive advantage. Ketiga, government policy dan commitment merupakan variabel moderator bagi hubungan KTI dengan competitive advantage. Sehingga hubungan-hubungan tersebut dapat digambarkan seperti Gambar 1 berikut.

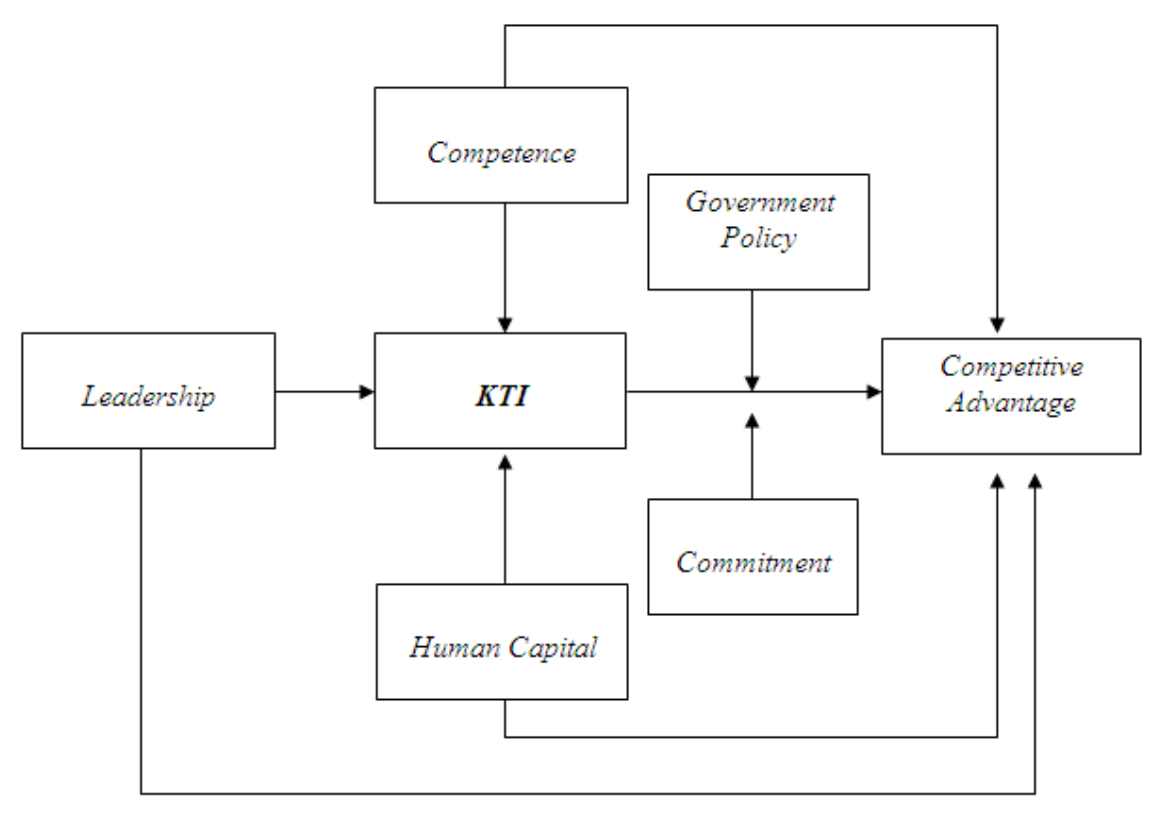

Gambar 1 Hubungan antara knowledge, technology, dan innovation (KTI), competitive advantage, commitment, leadership, human capital, government policy, dan competence 


\section{DAFTAR PUSTAKA}

Agbor, E. (2008). Creativity and innovation: the leadership dynamics. Journal of Strategic Leadership, 1(1), 39-45.

Agha, S., Alrubaiee, L., Jamhour, M. (2012). Effect of core competence on competitive advantage and organizational performance. International Journal of Business and Management, 7(1).

Alwis, R. S., \& Hartmann, E. (2008). The use of tacit knowledge within innovative companies: knowledge management in innovative enterprises. Journal of Knowledge Management, 12(1), 133-147.

Al-Zoubi, M. R. (2012). Leadership competencies and competitive advantage: empirical study on jordan telecommunication. European Journal of Business and Management, 4(7).

Arbussa, A., Coenders, G. (2005). Innovation strategies in the presence of technology markets: evidence from Spanish innovative firms. Working Papers, 15, 1-28.

Barney, J. B. (1991). Firm resources and sustained competitive advantage. Journal of Management, 17, 99-120.

Barringer, B. R., \& Ireland, R. D. (2013). Entrepreneurship: Successfully Launching New Ventures ( $4^{\text {th }}$ Edition). England: Pearson Education.

Benhabib, J., \& Spiegel M. M. (2002). Human capital and technology diffusion. FRBSF Working Paper \#2003-02.

Berry, L. L., et al. (2010). Opportunities for innovation in the delivery of interactive retail services. Journal of Interactive Marketing, 24, 155-167.

Collis, D. J., \& Montgomery, C. A. (2008). Competing on resources. Harvard Business Review, 140150 .

Costa, M. P. B., \& Cabral, J. E. O. (2009). The relationship knowledge, learning, innovation and competitive advantages: a conceptual model. The International Journal of Technology, Knowledge and Society.

Crawford, C. B. (2004). Transformational leadership, innovation and knowledge management: empirical findings and emergent conclusions. Transformational Leadership and Knowledge Management.

Damanpour, F., \& Schneider, M. (2008). Characteristics of innovation and innovation adoption in public organizations: assessing the role of managers. JPART, 19, 495-522.

Dae-Bong, K. (2009). Human Capital and Its Measurement, The $3^{\text {rd }}$ OECD World on Statistics, Knowledge and Policy.

David, F. R. (2013). Strategic Management: Concepts and Cases (14 ${ }^{\text {th }}$ Edition). Pearson Education.

David, P. A. \& Foray, D. (2002). Economic fundamentals of the knowledge society. Policy Futures in Education - an e-Journal, 1(1). http://www-siepr.stanford.edu/workp/swp02003.pdf

Denti, L. (2011). Leadership and Innovation: How and When do Leaders Influence Innovation in R \& D Terms? Dept of Psychology and Gothenburg Research Institute. 
De Bes, F. T., Kotler, P. (2011). Winning at Innovation: The A-to-F Model. New York: Palgrave Macmillan.

De Jong, J., den Hartog, D., Zoetermeer. (2003). Leadership as a determinant of innovative behavior. Research Report H200303, SCALES.

Edquist, C. (2001). System of Innovation for Development. United Nations Industrial Development Organization (UNIDO)

Estrin, J. (2009). Closing The Innovation Gap: Reigniting the Spark of Creativity in A Global Economy. New York: McGraw-Hill.

Folloni, G., Vittadini, G. (2010). Human capital measurement: a survey.Journal of Economic Surveys, 24(2), 248-279.

Fontana, A. (2011). Innovate We Can!: How to Create Value through Innovation in Your Organization and Society (Edisi Revisi). Bekasi: Cipta Inovasi Sejahtera.

Grant, R. M. (1996). Toward a knowledge-based theory of the firm. Strategic Management Journal, 17, 109-122.

Grant, R. M., \& Jordan, J. (2012). Foundations of Strategy. John Wiley \& Sons.

Greenwood, R., \& Pike, C. (2011). A Commitment to Place: The Social Foundations of Innovation in Newfoundland and Labrador. The Harris Centre Memorial University

Hana, U. (2013). Competitive advantage achievement through innovation and knowledge. Journal of Competitiveness, 5(1), 82-96.

Hisrich, R. D., Kearney, C. (2013). Corporate Entrepreneurship: How to Create A Thriving Entrepreneurial Spirit Throughout Your Company. New York: McGraw-Hill.

Hitt, M. A., Ireland, R. D., \& Hoskisson, R. E. (2012). Strategic Management: Concepts: Competitiveness and Globalization (10 ${ }^{\text {th }}$ Edition). Cengage Learning.

Hussain, M. F., \& Ilyas, S. (2011). Environment for innovation: gaining competitive advantage. African Journal of Business Management, 5(4), 1232-1235.

Jashapara, A. (2013). Knowledge Management: An Integrated Approach (2 ${ }^{\text {nd }}$ Edition). England: Pearson Education.

Kadiman, K. (2008). Membangun Daya Saing, Kemandirian Sains, dan Teknologi Bangsa, Sekretariat Negara Republik Indonesia.

Kandampully, J. (2002). Innovation as the core competency of a service organization: the role of technology, knowledge and networks. European Journal of Innovation Management, 5(1), 1826.

Karlsson, C., Johansson, B., Stough, R. R. (2012). Innovation, Technology and Knowledge. New York: Routledge.

Khan, S., \& Anjum, M. A. (2013). Role of leadership style and its impact on getting competitive advantage. European Journal of Applied Sciences, 5(2), 53-61. 
Lahovnik, M., \& Breznik, L. (2013). Innovation Management and Technological Capabilities As A Source Of Competitive Advantage. Knowledge and Learning-International Conference, Croatia.

Lindgren, R. et al. (2001). Rethinking Competence Systems for Innovative Organizations. The $9^{\text {th }}$ European Conference on Information Systems.

Luckanicova, M., Malikova, Z., A Comparative Study of Innovation Capacity From Human Capital Perspective on Regional Level: Study of Slovakia, VEGA 1/1046/11

Lundvall, B. A. (2003). The Economics of Knowledge and Learning. Aalborg University: Department of Business Studies.

Marrelli, A. F., Tondora, J., Hoge, M. A. (2005). Strategies for developing competency models. Administration and Policy in Mental Health, 32, (5/6). Springer Sciences+Business Media.

Muchtadi, T. R. (2008). Peran dan Dukungan Pemerintah Dalam Pengembangan dan Percepatan Alih Teknologi. Prosiding Seminar Nasional Teknologi Inovatif Pascapanen untuk Pengembangan Industri Berbasis Pertanian.

Murmann, J. P. (2003). Knowledge and Competitive Advantage: The Coevolution of Firms, Technology, and National Institutions. UK: Cambridge University.

Nelson, R. R., \& Romer, P. M. (1996). Science, Economic Growth, and Public Policy. M.E. Sharpe.

Nelson, R. R., \& Phelps, E. S. (1966). Investment in humans, technological diffusion, and economic growth. The American Economic Review, 56(1/2), 69-75.

Nieminen, H. (2007). Developing Competences through Inter-Organizational Knowledge Acquisition. Sarja/Series A-12. Turku School of Economics.

Nonaka, I., \& Krogh, G. V. (2009). Tacit knowledge and knowledge conversion: controversy and advancement in organizational knowledge creation theory. Organization Science, 20(3), 635652.

Nonaka, I., \& Toyama, R. (2003). The knowledge-creating theory revisited: knowledge creation as a synthesizing process. Knowledge Management Research \& Practice, 1, 2-10.

Northouse, P. G. (2012). Leadership: Theory and Practice (6 $6^{\text {th }}$ Edition). Sage.

Porter, M. E. (1990). The Competitive Advantage of Nations. Harvard Business Review

Powell, W. W., Snellman, K. (2004). The knowledge economy. Annual Review of Sociology, 30, 199220.

Probst, G. J. (1998). Practical Knowledge Management: A Model That Works. Prism/Second Quarter. http://genevaknowledgeforum.ch/downloads/prismartikel.pdf

Ricken, B., \& Malcotsis, G. (2011). Advantage of Regions and Nations: Technology Transfer Through Foreign Direct Investment. Gower Publishing.

Robbins, S. P., \& Judge, T. A. (2011). Organizational Behavior $\left(14^{\text {th }}\right.$ Edition). USA: Pearson Education.

Schaper, M., Volery, T., Weber, P., Lewis, K. (2013). Entrepreneurship and Small Business ( ${ }^{\text {rd }}$ AsiaPacifiq Edition). Australia: John Wiley \& Sons. 
Silverstein, D., Samuel, P., DeCarlo, N. (2009). The Innovator's Toolkit: 50+ Techniques for Predictable and Sustainable Organic Growth. New Jersey: John Wiley \& Sons.

Teece, D., G. Pisano. (1994). The dynamic capabilities of firms: an introduction. Industrial and Corporate Change, 3(3), 537-556.

Tidd, J., \& Bessant, J. (2009). Managing Innovation: Integrating Technological, Market and Organizational Change ( $4^{\text {th }}$ Edition). England: John Wiley \& Sons.

Thomke, S., Hippel., E., \& Franke, R. (1998). Modes of experimentation: an innovation process and competitive-variable. Research Policy, 27, 315-332.

Van der Spek, R., \& Kingma, J. (2000). Achieving Successful Knowledge Management Initiatives in Liberating Knowledge (Ed, Reeves, J.). London: Caspian.

Waheed, H., et al. (2013). Mediating role of knowledge sharing: organizational performance for competitive advantage and innovation. African Journal of Business Management, 7(7), 536547.

Wang, Hsing-Kuo., et al. (2008). An empirical research on the relationship between human capital and innovative capability: a study on taiwan's commercial banks. Total Quality Management, 19(11), 1189-1205.

Winston, B. E., \& Patterson, K. (2006). An integrative definition of leadership. International Journal of Leadership Studies, 1(2), 6-66.

Winterton, J., Le Deist, F. D., Stringfellow, E., (2006). Typology of Knowledge, Skills and Competence: Clarification of the Concept and Prototype. Luxembourg: Office for Official Publications of the European Communities.

Wright, P. M., McMahan, G. C., McWilliams, A. (1993). Human Resources and Sustained Competitive Advantage: A Resource-Based Perspective, Center Effective Organizations, University of Southern California.

Xu, B. (2000). Multinational enterprises, technology diffusion, and host country productivity growth. Journal of Development Economics, 62, 477-493.

Yukl, G. (2012). Leadership in Organizations (8 ${ }^{\text {th }}$ Edition). Prentice Hall.

Zack, M. H. (2003). What Is a Knowledge-Based Organization? Organizational Learning and Knowledge, $5^{\text {th }}$ International Conference.

Zingheim, P. K., Ledford, G. L., Schuster, J. R. (1996). Competencies and competency models: does one size fit all? ACA Journal, 5(1), 56-65. 